\title{
FINN INFORMASJON OM LEGEMIDLER FOR BARN
}

\section{/ helsebiblioteket.no}

\section{Av Hans Petter Fosseng, nettredaktør}

Synes du det er vanskelig å finne oppdatert fagkunnskap om legemidler og barn? Helsebiblioteket.no gir deg gratis tilgang til flere kilder med kvalitetssikret informasjon som er spesielt tilpasset yngre pasienter.

\section{UTFORDRING}

Hvordan går du fram når du skal gi et uregistrert preparat til en ung pasient? Manglende forskning på legemiddelbehandling på barn er en utfordring, og medikamentenes virkning er ikke alltid tilstrekkelig kjent (1). Et velkjent oppslagsverk som Felleskatalogen gir ingen svar i slike tilfeller og legemiddelets pakningsvedlegg er ikke på morsmålet ditt. Har du oppfattet informasjonen på pakningsvedlegget riktig? Det kan være mange detaljer å ta hensyn til ved administrasjon av legemiddelet, blant annet utblanding, videre fortynning, hastighet og interaksjoner med andre legemidler. Hvor leter du etter kvalitetssikret informasjon om legemidler for barn, hvis du ikke finner svar i Felleskatalogen eller vil dobbeltsjekke det du vet med andre kunnskapskilder?

\section{TILPASSET INFORMASJON}

Gjennom Helsebiblioteket.no har du gratis tilgang til legemiddeldatabasen British National Formulary for Children (BNF for Children). Dette er en kunnskapsressurs med tilpasset, praksisrettet informasjon om bruk av legemidler til barn og ungdom. Innholdet i databasen vurderes fortløpende mot ny kunnskap, pediatriske retningslinjer og råd fra et nettverk av kliniske eksperter.
BNF for Children er laget for at du skal kunne gjøre raske oppslag og dermed ha et nyttig verktøy i den kliniske hverdagen. I denne databasen får du blant annet anbefalinger om «off label»-bruk på barn, en type informasjon du ikke finner så lett i andre kilder. Generelle kapitler og terapi- og legemiddelkapitler er innganger til innholdet. I tillegg kan du bruke søkefeltet til å finne informasjon om for eksempel et spesifikt legemiddel. Databasen inneholder også generelle råd rundt forskriving til barn, bivirkninger, interaksjoner, graviditet og amming (2).

Hvis vi ser for oss at du har behov for råd rundt bruk av analgetika av opiattypen, kan du prøve et søk på for eksempel «pain relief» i BNF for Children. Ett av treffene er artikkelen «Opioid analgesics», som er en detaljert gjennomgang av temaet, med råd om hvordan bruke legemidler mot moderate til sterke smerter. Går du videre til artikkelen «Prescribing in palliative care», får du blant annet presentert en oversikt over anbefalt dosering. På Helsebiblioteket.no finner du BNF for Children under menyvalget «Databaser».

\section{INNHOLDSRIKE KILDER}

I Lexicomp, en av verdens mest omfattende og anerkjente legemiddeldatabaser, finner du en egen seksjon for helsepersonell som jobber med pediatriske pasienter. Fra startsiden finner du «Pediatric and Neonatal Lexi-Drugs» via menyvalget «Drugs». Denne databasen inneholder detaljert informasjon og retningslinjer som er gjennomgått av spesialister innen pediatri. Den inkluderer over 900 legemidler, med artikler som dekker nesten 50 informasjonsområder, inkludert detaljert informasjon om nyfødt-og pediatrisk dosering (3). Likevel er det ofte hensiktsmessig å starte letingen i den generelle delen av Lexicomp (Lexi-Drugs), også med tanke på informasjon om yngre pasientgrup- 


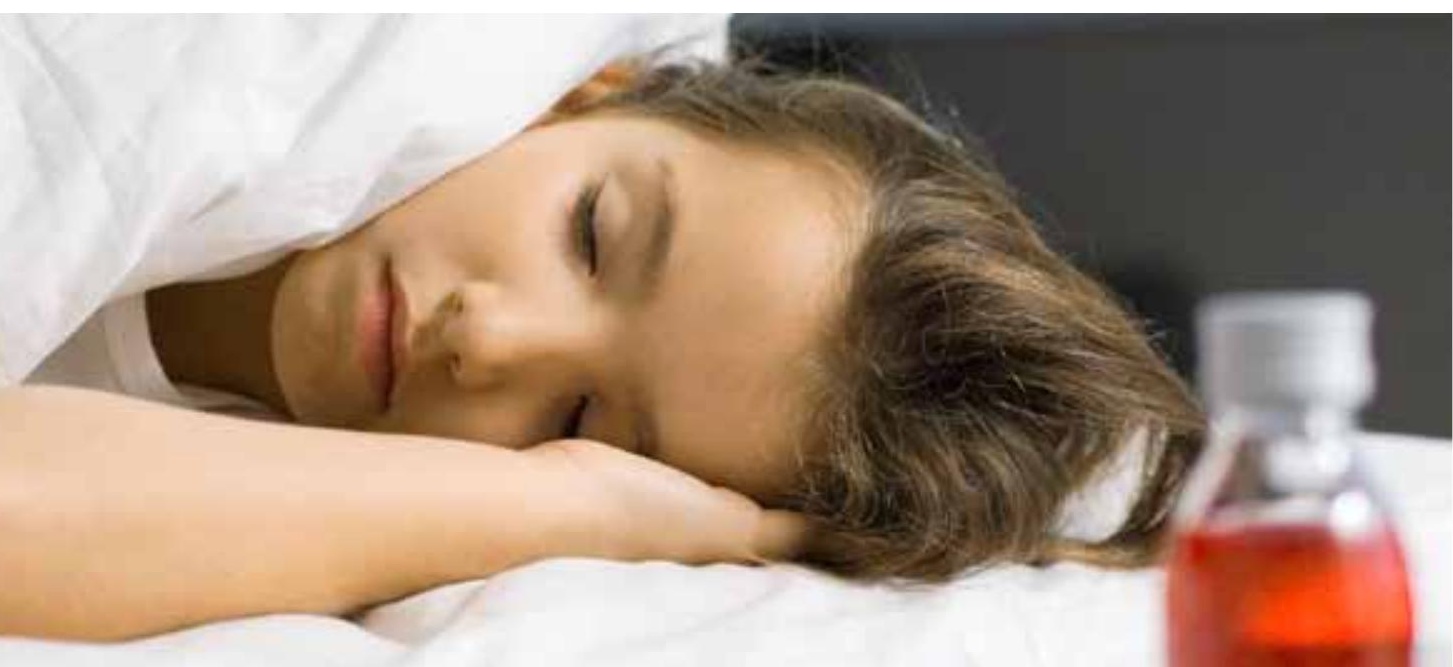

per. Hovedårsaken er at du her vil få fram det norske generiske- og preparatnavnet. Spesielt nyttig er kanskje pakningsvedlegg på mange språk, som kan fungere som et praktisk kommunikasjonsmiddel i pasientmøtet. Du kan lese på ditt morsmålog tilby samme informasjon til pasienter og pårørende på deres eget morsmål. Informasjon tilpasset pediatri er å finne under en egen arkfane på siden.

I tillegg til den vanlige nettversjonen har du i Norge gratis tilgang til Lexicomp som applikasjon 
for håndholdte enheter som nettbrett og smarttelefoner. Fordelen med å laste ned denne applikasjonen er at du bokstavelig talt kan ta med deg hele databasen i lomma, uten behov for nettilgang. Andre kvalitetskilder som kan være aktuelle, er de kliniske oppslagsverkene BMJ Best Practice og UpToDate, begge fritt tilgjengelig i Norge gjennom Helsebibliotekets avtaler. UpToDate inneholder mye relevant informasjon om legemidler og yngre pasientgrupper. Uavhengig av hva du søker etter, kan du i trefflisten alltid avgrense til kun å vise innhold relatert til barn og ungdom (velg «Pediatric»). I BM J Best Practice finner du kapitler om for eksempel legemidler og astma, og behandling av feber med ukjent årsak.

\section{NORSKSPRÅKLIGE KILDER}

Det finnes også en rekke norske kilder hvor du kan finne nyttig informasjon om legemidler og barn. Blant annet inneholder Norsk legemiddelhåndbok et kapittel om emnet. Her blir det lagt vekt på at legemidler som regel er utviklet og utprøvd på voksne og at godkjent indikasjon ofte er til voksne. Ifølge Legemiddelhåndboka er opp mot 90 prosent av legemidler som brukes til barn i sykehus, ikke godkjent for aktuell bruk («off label»-bruk). Dette krever en spesiell aktsomhet, noe et godt kunnskapsgrunnlag fra relevante fagressurser kan bidra til. I Legemiddelhåndboka finner du også informasjon om amming og legemidler. Norsk barnelegeforenings Generell veileder i pediatri gir råd om bruk og håndtering av legemidler til barn. Veilederen er rettet mot leger, men kan også være av nytte for annet helsepersonell som jobber med barn og ungdom. Nettsidene til Nasjonalt kompetansenettverk for legemidler til barn er også en kilde til informasjon. Anbefalt litteratur om barn og legemidler og en spørsmål- og svarseksjon er blant innholdet.

\section{FORGIFTNINGER}

Behandlingsanbefalinger fra Giftinformasjonen om akutte forgiftninger finner du på Emnebibliotek forgiftninger på Helsebiblioteket.no. Denne informasjonen er rettet mot helsepersonell, mens publikumsinformasjon om forgiftninger er å finne på det offentlige nettstedet Helsenorge.no. Giftinformasjonen har døgnvakt på telefon 22591300.

Det kan være nyttig å kjenne til hvilken pasientinformasjon som er tilgjengelig på Internett, slik at du kan veilede pasienter og pårørende som har behov for mer informasjon. Felleskatalogen har en egen seksjon med pasientinformasjon hvor du finner legemidlenes pakningsvedlegg. Pasientinformasjonsnettstedet NHI.no har flere artikler relatert til legemiddelbruk og barn, for eksempel informasjon til foreldre om hvordan gi rett medisin til rett tid. Apotekforeningen tilbyr 18 brosjyrer beregnet på småbarnsforeldre fra nettstedet. På www.legemiddelbruk.no, som Sykehusapotekene i Midt-Norge står bak, finner du videosnutter for barn og foreldre. Temaene varierer fra inhalasjon til hvordan gi mikstur til barn. Et tips til slutt er å søke på preparatnavn, virkestoff eller ATC-kode i det generelle søket på Helsebiblioteket. no. Søket gir deg blant annet praktiske snarveier til pakningsvedlegg og interaksjoner fra flere sentrale kilder - alt i ett treff. Kildene er blant annet DRUID, Felleskatalogen og Legemiddelhåndboka.

Alle kilder som er omtalt i denne artikkelen finner du via Emnebibliotek legemidler på Helsebiblioteket. no: www.helsebiblioteket.no/legemidler.

\section{REFERANSER}

1. Kalikstad B, Hansen TWR. Medikamentell behandling av nyfødte - et sjansespill? Tidsskr Nor Legeforen 2003; 123:2738-40

2. Fosseng HP. Legemiddelinformasjon for barn og unge. Dagens medisin 2009 (19): 48.

3. Rotvik IM. Fri tilgang til omfattende legemiddeldatabase. Helsebiblioteket.no 4.2.2009. www. helsebiblioteket. no/30288.cms 